\title{
CHARACTERISTICS OF ORANGE-WHEY FERMENTED BEVERAGES
}

\author{
K. PoGoŃ*a, M. SAdY ${ }^{b}$, G. JAWORSKA a and T. GREGA ${ }^{b}$ \\ a.Department of Fruit, Vegetable and Mushroom Technology, Agricultural University of Krakow, \\ 122 Balicka Street, 30 - 149 Krakow. Poland \\ ${ }^{\mathrm{b}}$ Department of Processing of Animal Products, Agricultural University of Krakow, \\ 122 Balicka Street, 30 - 149 Krakow. Poland
}

(Received: 20 July 2012; accepted: 20 July 2013)

\begin{abstract}
The aim of the present work was to determine the populations of ABT culture microorganisms in orange and orangewhey drinks after fermentation and during 28-day storage. The evaluation involved fermented fruit drinks without whey or with added acid or sweet (rennet) whey. The Streptococcus thermophilus and Bifidobacteria counts were

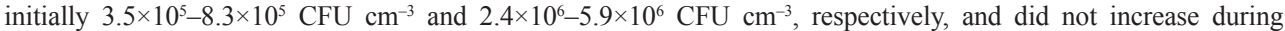
fermentation. However, an increase was observed in the Lb. acidophilus count, which amounted to $3.0 \times 10^{6}-2.4 \times 10^{7}$ $\mathrm{CFU} \mathrm{\textrm {cm } ^ { - 3 }}$ after fermentation. During storage, the Str. thermophilus and Lb. acidophilus counts remained constant, but

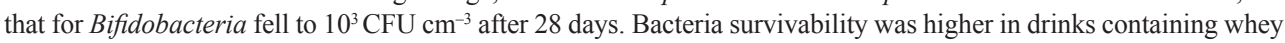
than in non-whey orange drinks. In $100 \mathrm{~cm}^{3}$, antioxidant activity against ABTS/DPPH radicals varied between 260 and $550 \mu \mathrm{mol} \mathrm{TE}$; vitamin $\mathrm{C}$ content was in the range of $15.7-17.6 \mathrm{mg}$; polyphenols were $26.6-34.4 \mathrm{mg}(+)$ catechin. In the sensory evaluation the best results were obtained for non-whey drinks and those containing $50 \%$ acid whey.
\end{abstract}

Keywords: whey, fruit beverages, fermentation, antioxidant activity

The development of cheese making and increased demand for all types of cheese have created the problem of utilising industrial quantities of whey, of which about 1.1 million $t$ is produced in Poland annually and the figure is rising (RAsz, 2009). One way of processing whey is the production of whey-based drinks (HoLSINGER et al., 1974).

Whey-based fruit drinks could provide an interesting alternative to classic fruit juices and drinks. Functional properties of whey-based fruit drinks would stem from bioactive components of whey, especially proteins and vitamin B (ONwULATA \& HuTH, 2008), and from vitamin $\mathrm{C}$ and $\beta$-carotene, mineral salts, dietary fibre, and phenolic compounds of fruits with high antioxidant activity (MiteK \& Kalisz, 2003; Gruenwald, 2009). A particularly attractive feature for consumers might be the addition of live probiotic cultures to such drinks (FRIC, 2007). Health benefits of ingesting live probiotic bacteria are extensively described in the literature.

The aim of the present work was to determine whether fermentation of whey based fruit beverages with ABT culture is possible and how the storage affects the number of live bacteria cells. The populations of Streptococcus thermophilus, Lactobacillus acidophilus, and Bifidobacterium ssp. in orange and orange-whey beverages during the course of fermentation with ABT culture and after 28 days of storage were estimated. The beverages contained different amounts of added sweet (rennet) or acid whey and were fermented using ABT cultures. In addition, selected physicochemical parameters were analysed and a sensory evaluation was carried out.

* To whom correspondence should be addressed

Phone: +48 12 6624754; fax: +48 12 6624757; e-mail: kpogon@ur.krakow.pl

0139-3006/\$20.00 C 2014 Akadémiai Kiadó, Budapest 


\section{Materials and methods}

\subsection{Materials}

The study material consisted of beverages obtained from the production in the laboratory of the Agricultural University in Krakow. The drinks were produced using Cristal 1 low mineral natural spring water (Wosana S.A., Poland); orange concentrate comprising 64\% extract with $3.85 \mathrm{~g}$ citric acid in $100 \mathrm{~g}$ (imported from Brazil); and sweet (rennet) and acid whey from Miechow District Dairy Cooperative (OSM Miechow, Poland). Beverages contained $12 \pm 0.2 \%$ extract, of which $50 \%$ would be orange concentrate complemented with sugar and dry matter from whey.

The following orange-flavour drinks were produced: (i) $\mathrm{C}$ : (control beverage) - nonwhey; (ii) A50: beverage with 50\% water substituted by acid whey; (iii) A100: beverage with $100 \%$ water substituted by acid whey; (iv) S50: beverage with $50 \%$ water substituted by sweet (rennet) whey; (v) S100: beverage with 100\% water substituted by sweet (rennet) whey.

After blending the ingredients, the beverages were pasteurised at $90{ }^{\circ} \mathrm{C}$ for $30 \mathrm{sec}$, cooled and inoculated with Direct Vat Set type ABT-1 culture (CHR Hansen, Denmark) containing Str. thermophilus, Lb. acidophilus, and Bifidobacterium ssp. The beverages were then bottled (0.33 1); incubated at $37^{\circ} \mathrm{C}$ for $10 \mathrm{~h}$; cooled to $4{ }^{\circ} \mathrm{C}$; and stored pending analysis.

\subsection{Microbiological analysis}

Microbiological analysis was carried out: before fermentation; after fermentation; after 14 and 28 days of storage. Microorganism populations were determined by plate count as follows: Str. thermophilus on M17 agar medium after $48 \mathrm{~h}$ incubation at $37^{\circ} \mathrm{C} ;$ Lb. acidophilus on MRS agar medium after $72 \mathrm{~h}$ incubation at $37^{\circ} \mathrm{C}$; Bifidobacterium ssp. on MRS-NNLP (i.e. with added neomycin, nalidixic acid, lithium chloride, and paromomycine sulphate) agar medium after $72 \mathrm{~h}$ anaerobic incubation at $37{ }^{\circ} \mathrm{C}$. Yeast and mould contamination was ascertained from the culture on the agar medium using chloramphenicol incubation for 5 days under $20{ }^{\circ} \mathrm{C}$. Special media supplied by Merck were used.

\subsection{Physicochemical parameters}

Physicochemical analysis and sensory evaluation were carried out after 28 days of storage. Total acidity was determined by the A.O.A.C. method (1995). Vitamin C and L-ascorbic acid content was determined by titration with 2,6-dichlorophenolindophenol according to Polish Standard (1998).

Total polyphenols were assayed by means of the Folin-Ciocalteu reagent (SINGLETON et al., 1999), while antioxidant activity against DPPH radical (1,1-diphenyl-2-picrylhydrazyl) and cation radical ABTS (2.2-azino-bis [3-ethylbenzthiazoline-6 sulphonic acid]) was assessed by the methods described by PeKKARINEN and co-workers (1999) and Re and coworkers (1999).

Colour measurement was carried out instrumentally according to the CIE system using a Minolta CM-3500d spectrophotometer. Based on that measurement, the following parameters were established: $\mathrm{L}^{*}$ : colour brightness ( $\mathrm{L}^{*}=0$ black, $\mathrm{L}^{*}=100$ white); $\mathrm{a}^{*}$ : green colour $\left(a^{*}<0\right)$, red colour $\left(a^{*}>0\right)$; $b^{*}$ : blue colour $\left(b^{*}<0\right)$, yellow colour $\left(b^{*}>0\right)$. 
Sensory analysis was also carried out according to PN-ISO Standard (1998). The results of the evaluation were determined on the basis of points awarded for each trait according to a 5-point scale, and significance coefficients.

\subsection{Statistical analysis}

The investigation was carried out in three series and two replications $(n=6)$. Statistica 8.0 (Stat-Soft) software was used for statistical analysis. The results of microbiological analysis were subject to multivariate analysis of variance (ANOVA), using Duncan's multiple range test to determine the significance of differences between means at significance level $\alpha=0.05$. The results of the physicochemical investigation were analyzed statistically using one-way analysis of variance based on the F-Snedecor test and Student $t$-test at $\alpha=0.05$.

\section{Results and discussion}

\subsection{Microbiological analysis}

Among the lactic acid bacteria present in ABT culture, the lowest count found in beverages was for Str. thermophilus and the results are presented in Figure 1A. The amount of Str. thermophilus in orange-whey drinks was initially $3.5 \times 10^{5}-8.3 \times 10^{5} \mathrm{CFU} \mathrm{cm}^{-3}$, which comprised $28-30 \%$ of all studied bacteria present in the beverages. These levels did not increase during fermentation (statistical analysis of bacteria count presented in Table 1). The number of live cells in milk inoculated with $\mathrm{ABT}$ culture intended for yoghurt production increased from $10^{6} \mathrm{CFU} \mathrm{cm}{ }^{-3}$ to approximately $10^{8}-10^{9} \mathrm{CFU} \mathrm{cm}{ }^{-3}$ during fermentation (DAVE \& Shaн, 1997; Shiнata \& Sнан, 2002). The Str. thermophilus count remained stable up to the 14 th day of storage; thereafter, by day 28 , there was a significant decrease of $46 \%$ in control beverage and up to $14 \%$ in beverages containing whey observed. The number of Str. thermophilus cells in yoghurt made with ABT culture can fall by 50 to $70 \%$ during 1 month of storage (DAVE \& SHAH, 1997). In beverages containing whey the Str. thermophilus count was almost one logarithmic unit greater than in the control beverage. Moreover, bacteria survivability was better in beverages containing whey, although no differences were found between the types of whey used (sweet or acid). This shows the stabilising effect of whey on the level of the aforementioned microorganisms during storage. The main reason for the weak growth of Str. thermophilus in the beverages analysed was probably their high acidity. The greater survivability of this microorganism in beverages containing whey than in the control sample is explained by the fact that whey contains amino acids such as leucine and valine that are essential to the growth of this bacterium. GARAULT and co-workers (2000) pointed out that in order to grow, Str. thermophilus requires sufficient quantities of these amino acids in the medium, since the possibility of synthesis is limited.

The results for Lb. acidophilus are given in Figure 1B. The number of live cells in orange-whey drinks was initially $5.2 \times 10^{6}-7.2 \times 10^{6} \mathrm{CFU} \mathrm{cm}^{-3}$, rising to $1.0 \times 10^{7}-2.4 \times 10^{7}$ $\mathrm{CFU} \mathrm{\textrm {cm } ^ { - 3 }}$ after fermentation, an average increase of a half logarithmic unit. Only in the control beverage (non-whey) was there no growth in the number of Lb. acidophilus live cells. Lactobacillus acidophilus was the most abundant of the microorganisms added in ABT culture (35-45\%) and the only one to clearly show growth during fermentation. The opposite tendency was observed when the culture was used to make yoghurt, where growth of $L b$. acidophilus was low and that of Str. thermophilus high (Dave \& SHaH, 1997; Shinata \& SHaH, 
A
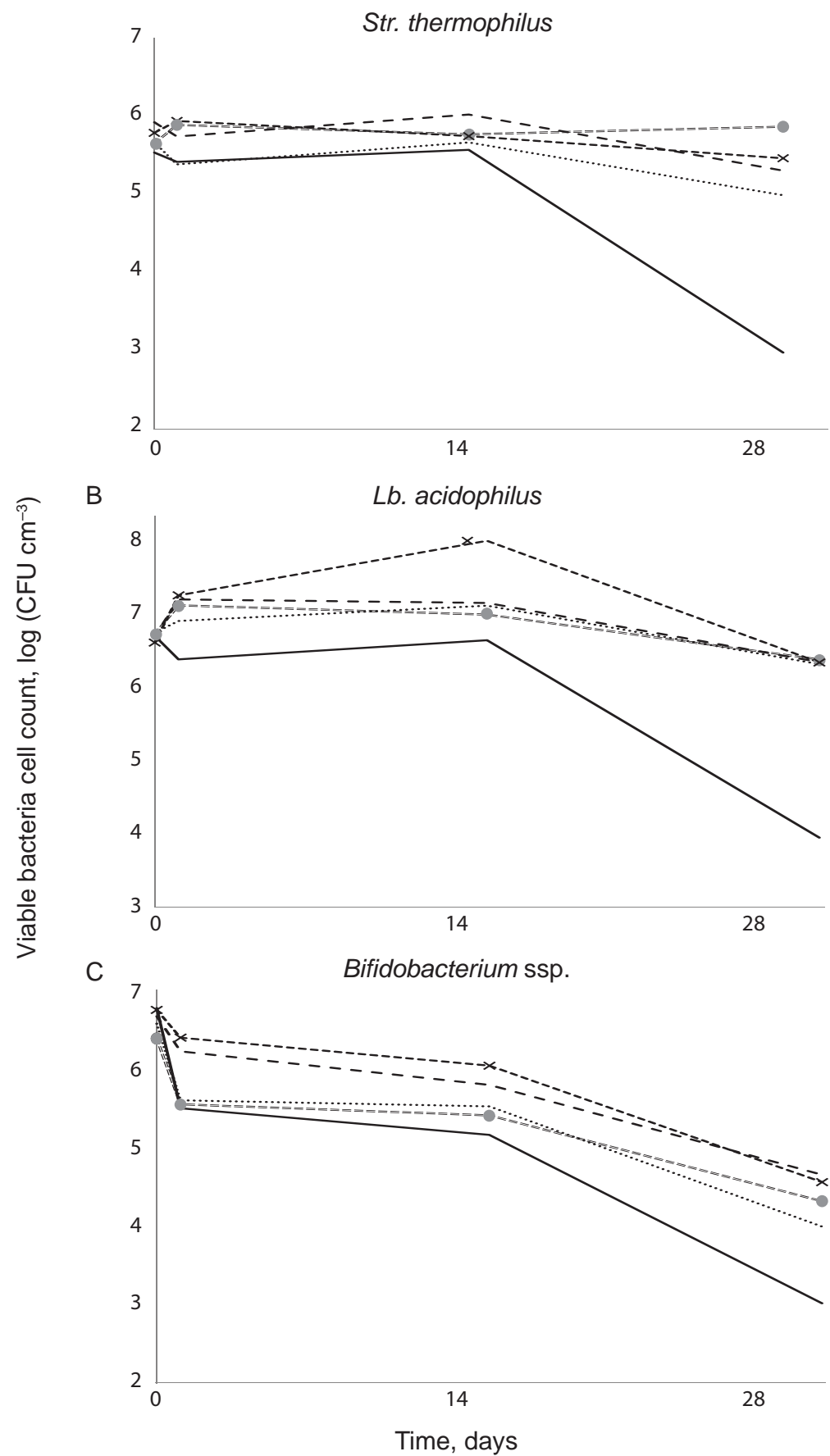

Fig. 1. Count of viable bacteria cells during fermentation and over 28 days of storage in orange-whey beverages. -: C (orange beverage); — _: A50 (orange beverage with 50\% acid whey);

--×--: A100 (orange beverage with 100\% acid whey); =0=: S50 (orange beverage with 50\% sweet whey); . . . . - S100 (orange beverage with 100\% sweet whey) 
Table 1. Statistical analysis of bacteria viability -

differences between least squares means from ANOVA multivariable test

\begin{tabular}{|c|c|c|c|c|c|c|c|c|c|c|}
\hline \multirow[t]{3}{*}{ Species of bacteria } & \multicolumn{10}{|c|}{ Variable } \\
\hline & \multicolumn{3}{|c|}{ Type of whey } & \multicolumn{3}{|c|}{ Share of whey } & \multicolumn{4}{|c|}{ Time of storage (days) } \\
\hline & Control & $\begin{array}{l}\text { Acid } \\
\text { whey }\end{array}$ & $\begin{array}{l}\text { Sweet } \\
\text { whey }\end{array}$ & $0 \%$ & $50 \%$ & $100 \%$ & 0 & 1 & 14 & 28 \\
\hline Str. thermophilus & $4.88^{\mathrm{a}}$ & $5.74^{\mathrm{b}}$ & $5.61^{b}$ & $4.88^{\mathrm{a}}$ & $5.77^{b}$ & $5.58^{\mathrm{b}}$ & $5.71^{\mathrm{a}}$ & $5.68^{\mathrm{a}}$ & $5.76^{\mathrm{a}}$ & $4.92^{b}$ \\
\hline Lb. acidophilus & $6.01^{\mathrm{a}}$ & $7.07^{\mathrm{b}}$ & $6.90^{\mathrm{b}}$ & $6.01^{\mathrm{a}}$ & $6.94^{\mathrm{b}}$ & $7.03^{\mathrm{b}}$ & $6.81^{\mathrm{a}}$ & $7.09^{\mathrm{a}, \mathrm{b}}$ & $7.31^{\mathrm{b}}$ & $5.95^{\mathrm{c}}$ \\
\hline Bifidobacterium ssp. & $5.11^{\mathrm{a}}$ & $5.88^{\mathrm{b}}$ & $5.42^{\mathrm{c}}$ & $5.11^{\mathrm{a}}$ & $5.42^{\mathrm{b}}$ & $5.68^{b}$ & $6.63^{\mathrm{a}}$ & $5.85^{\mathrm{a}}$ & $5.58^{\mathrm{c}}$ & $4.11^{\mathrm{d}}$ \\
\hline
\end{tabular}

a-d: different letters represent statistical differences between samples concerning one variable and bacteria species $(\alpha=0.05)$

2002). Moreover, DAVE and SHAH (1997) claimed that it is impossible to achieve sufficient survivability of $L b$. acidophilus in yoghurt made with ABT culture due to its sensitivity to such factors as acidity and the composition of the medium. The stability of these bacteria in whey beverages during storage was satisfactory and the number of live cells did not fall below $10^{6} \mathrm{CFU}$ in $1 \mathrm{ml}$ of beverage during 28 days. The addition of whey brought about a significant increase in the number of live cells compared with the control sample, but the proportion and type of whey did not affect this parameter. Research by KaILASAPATHY and SUPRIADI (1996) showed that the number of Lb. acidophilus cells was greater in yoghurt containing whey protein concentrate than in traditional yoghurt. CAPELA and co-workers (2006) demonstrated that prebiotics significantly improve the survivability of probiotic bacteria in various products. The beverages produced were naturally cloudy and contained dietary fibre, which may explain the greater stability of such sensitive bacteria in these beverages compared with yoghurt.

Bifidobacterium ssp. made up 31-34\% of the microflora in the beverages investigated immediately after fermentation. In yoghurt fermented with ABT culture, these bacteria were the least abundant of the microflora found following fermentation, although their actual content increased by at least one logarithmic unit per millilitre of product (DAvE \& SHAH, 1997; Sннната \& Sнан, 2002). During fermentation not only did the Bifidobacterium ssp. count not rise from the level of $2.4 \times 10^{6}-5.9 \times 10^{6} \mathrm{CFU} \mathrm{cm}^{-3}$, but actually fell after fermentation, the decrease being statistically significant. The tendency to decrease continued throughout the storage period so that by day 28 the level of Bifidobacterium ssp. had fallen to just $1.0 \times 10^{3}-4.5 \times 10^{4} \mathrm{CFU} \mathrm{cm}^{-3}$, comprising $26-30 \%$ of microorganisms in the beverages. The high sensitivity of many strains of Bifidobacterium ssp. to acid environment and the relatively low level of nutrients in the beverages are the most likely reason why the number of live cells did not increase during fermentation as they do in yoghurt made with ABT cultures (DAVE \& Shah, 1997; Shinata \& Shah, 2002). Shimamura and Ishibashi (1993) and Rosenthal and BERNSTEIN (1998) particularly stress that two factors essential for the growth of bifidobacteria are appropriately high $\mathrm{pH}$ and an anaerobic environment. The addition of whey had a beneficial effect on the survivability of bifidobacteria in beverages; the proportion of whey was not of significance. It was found that bacteria survivability was significantly better in beverages containing acid whey than in those containing sweet whey. This suggests that the composition of beverages is more significant than their acidity for the microorganisms investigated.

No contamination by yeasts or moulds was detected. 


\subsection{Physicochemical parameters}

Total acidity of the beverages varied between 0.42 and $0.66 \mathrm{~g}$ citric acid in $100 \mathrm{~cm}^{3}$ (Table 2), differences resulting from quantity and type of whey used in the beverage.

Total polyphenol levels in $100 \mathrm{~cm}^{3}$ whey beverages were 31.8-34.6 mg expressed as (+)-catechin, compared with $26.6 \mathrm{mg}$ in the (non-whey) control beverage (Table 2). According to ZAJĄC and PoDSĘDEK (2002), average polyphenol content in fruit beverages available on the Polish market is $65 \mathrm{mg}(+)$-catechin in $100 \mathrm{~cm}^{3}$ beverage. Differences in total polyphenols between the control sample and whey beverages, despite both having the same proportion of orange concentrate, are attributable to the presence of protein compounds, which can also react with the Folin-Ciocalteu reagent (Oкuтucu et al., 2007). Methanol extracts of both types of whey used for the beverages examined with Folin-Ciocalteu reagent showed positive reaction.

Table 2. Physicochemical parameters, colour, and total sensory assessment of beverages

\begin{tabular}{|c|c|c|c|c|c|c|}
\hline \multicolumn{2}{|l|}{ Parameter } & $\begin{array}{c}\mathrm{C} \\
\text { (orange } \\
\text { beverage) }\end{array}$ & $\begin{array}{c}\text { A50 } \\
\text { (orange } \\
\text { beverage with } \\
50 \% \text { acid } \\
\text { whey) }\end{array}$ & $\begin{array}{c}\text { A100 } \\
\text { (orange } \\
\text { beverage with } \\
100 \% \text { acid } \\
\text { whey) }\end{array}$ & $\begin{array}{c}\text { S50 } \\
\text { (orange } \\
\text { beverage with } \\
50 \% \text { sweet } \\
\text { whey) }\end{array}$ & $\begin{array}{c}\text { S100 } \\
\text { (orange } \\
\text { beverage with } \\
100 \% \text { sweet } \\
\text { whey) }\end{array}$ \\
\hline \multicolumn{2}{|l|}{$\begin{array}{l}\text { Acidity } \\
\left(\text { citric acid g/100 } \mathrm{cm}^{3}\right)\end{array}$} & $0.42 \pm 0.02^{\mathrm{a}}$ & $0.52 \pm 0.01^{\mathrm{b}}$ & $0.66 \pm 0.02^{\mathrm{c}}$ & $0.43 \pm 0.02^{\mathrm{a}}$ & $0.49 \pm 0.02^{\mathrm{a}, \mathrm{b}}$ \\
\hline \multicolumn{2}{|l|}{$\begin{array}{l}\text { Total polyphenol content } \\
\left((+) \text {-catechin } \mathrm{mg} / 100 \mathrm{~cm}^{3}\right)\end{array}$} & $26.63 \pm 1.24^{\mathrm{a}}$ & $32.23 \pm 0.25^{\mathrm{b}}$ & $31.68 \pm 2.39^{b}$ & $32.80 \pm 2.27^{b}$ & $34.35 \pm 1.35^{\mathrm{b}}$ \\
\hline \multicolumn{2}{|l|}{$\begin{array}{l}\text { Antioxidant activity [ABTS] } \\
\left(\mathrm{TE} \mu \mathrm{mol} / 100 \mathrm{~cm}^{3}\right)\end{array}$} & $426 \pm 39^{a}$ & $550 \pm 18^{b}$ & $484 \pm 42^{\mathrm{c}}$ & $525 \pm 19^{b}$ & $480 \pm 9^{c}$ \\
\hline \multicolumn{2}{|l|}{$\begin{array}{l}\text { Antioxidant activity [DPPH] } \\
\left(\mathrm{TE} \mu \mathrm{mol} / 100 \mathrm{~cm}^{3}\right)\end{array}$} & $344 \pm 19^{a}$ & $374 \pm 14^{b}$ & $340 \pm 11^{\mathrm{a}}$ & $416 \pm 8^{c}$ & $368 \pm 5^{\mathrm{b}}$ \\
\hline \multicolumn{2}{|l|}{$\begin{array}{l}\text { Vitamin C } \\
\left(\mathrm{mg} / 100 \mathrm{~cm}^{3}\right)\end{array}$} & $17.4 \pm 1.4^{\mathrm{a}}$ & $17.6 \pm 0.8^{\mathrm{a}}$ & $17.6 \pm 0.4^{\mathrm{a}}$ & $18.6 \pm 0.6^{\mathrm{a}}$ & $16.7 \pm 1.4^{\mathrm{a}, \mathrm{b}}$ \\
\hline \multicolumn{2}{|l|}{$\begin{array}{l}\text { L-ascorbic acid } \\
\left(\mathrm{mg} / 100 \mathrm{~cm}^{3}\right)\end{array}$} & $15.3 \pm 0.5^{\mathrm{a}}$ & $15.0 \pm 0.5^{\mathrm{a}}$ & $14.5 \pm 0.6^{\mathrm{a}}$ & $14.6 \pm 0.5^{\mathrm{a}}$ & $13.8 \pm 0.4^{\mathrm{a}}$ \\
\hline \multirow[t]{3}{*}{ Colour parameters } & $\mathrm{L}^{*}$ & $55.3 \pm 0.7^{\mathrm{a}}$ & $53.4 \pm 0.1^{\mathrm{a}}$ & $53.1 \pm 0.6^{\mathrm{a}}$ & $45.5 \pm 0.3^{\mathrm{b}}$ & $38.8 \pm 1.1^{\mathrm{c}}$ \\
\hline & $a^{*}$ & $3.7 \pm 0.5^{\mathrm{a}}$ & $3.6 \pm 0.4^{\mathrm{a}}$ & $4.1 \pm 0.2^{\mathrm{b}}$ & $5.0 \pm 0.4^{\mathrm{c}}$ & $8.3 \pm 0.4^{\mathrm{d}}$ \\
\hline & $b^{*}$ & $49.3 \pm 0.6^{\mathrm{a}}$ & $52.0 \pm 0.1^{\mathrm{b}}$ & $54.6 \pm 0.4^{\mathrm{c}}$ & $54.6 \pm 1.2^{\mathrm{c}}$ & $57.9 \pm 0.5^{\mathrm{d}}$ \\
\hline \multicolumn{2}{|l|}{ Total sensory assessment } & $4.94 \pm 0.10^{\mathrm{a}}$ & $4.83 \pm 0.15^{\mathrm{a}}$ & $4.49 \pm 0.23^{\mathrm{b}}$ & $3.90 \pm 0.36^{\mathrm{c}}$ & $3.15 \pm 0.32^{\mathrm{d}}$ \\
\hline
\end{tabular}

mean value $\pm \mathrm{sd}$; ${ }^{\mathrm{a}-\mathrm{d}}$ : different letters represent statistical differences between samples concerning one variable $(\alpha=0.05)$

Antioxidant activity against the cation radical ABTS was significantly lower in the control sample $\left(426 \mu \mathrm{mol} \mathrm{TE} / 100 \mathrm{~cm}^{3}\right)$ than in whey beverages $\left(480\right.$ to $\left.550 \mu \mathrm{mol} \mathrm{TE} / 100 \mathrm{~cm}^{3}\right)$. Activity against ABTS was $10-12 \%$ higher in beverages containing $50 \%$ whey than in those containing $100 \%$. The type of whey did not have a significant effect on this parameter. Antioxidant activity against the DPPH radical varied between 340 and $416 \mu \mathrm{mol}$ TE in $100 \mathrm{~cm}^{3}$. The highest activity was found in sweet whey beverages and was $7-20 \%$ higher than in beverages with $100 \%$ acid whey, which had the lowest anti-DPPH activity. It was also 
observed that anti-DPPH activity in 50\% whey beverages was $10-13 \%$ higher than in $100 \%$ whey beverages. Orange juices investigated by МıтеK and KALISz (2003) exhibited antioxidant activity of $220-800 \mu \mathrm{mol} \mathrm{TE}$ in $100 \mathrm{~cm}^{3}$. In the light of this, the antioxidant capacity of the beverages examined was relatively high.

The vitamin $\mathrm{C}$ present in the examined beverages came from the orange concentrate, since it is not found in whey. Vitamin C content ranged from 15.7 to $17.6 \mathrm{mg}$ in $100 \mathrm{~cm}^{3}$ (Table 2), of which $80-88 \%$ was L-ascorbic acid. Such levels of vitamin $\mathrm{C}$ mean that one glass of beverage would supply $45-70 \%$ of the adult daily requirement.

\subsection{Colour analysis}

Instrumental colour analysis revealed relatively high $\mathrm{L}^{*}$ parameter values in orange-whey beverages and the presence of red and yellow colours represented by the values of $\mathrm{a}^{*}$ and $\mathrm{b}^{*}$ parameters (Table 2). The addition of whey had a significant effect on the values of colour parameters in orange beverages, both the type and proportion of whey were of importance. Greater changes in comparison with control beverage were observed in beverages with $100 \%$ addition of whey and in beverages prepared with sweet whey. Values of colour parameters $\mathrm{L}^{*}, \mathrm{a}^{*}$, and $\mathrm{b}^{*}$ for the investigated beverages were similar to those typically given in the literature for orange juices (Esteve et al., 2005). This is a favourable feature, since a product's colour is an important factor in consumer purchase decisions.

\subsection{Sensory analysis}

The sensory evaluation of beverages showed that the orange drink without added whey was the most acceptable, scoring 4.94 in the general evaluation (Table 2). Acid whey beverages scored substantially better than sweet whey beverages, and beverages with $50 \%$ added whey were more favourably evaluated that those with $100 \%$ added whey.

\section{Conclusion}

The present investigation could provide the basis for establishing technology for the production of fruit-whey beverages with probiotics. Whey had a beneficial effect on the number of live lactic acid bacteria in examined orange-whey beverages. Nevertheless examined beverages do not seem to be the most suitable medium for microorganism present in ABT culture, since little or no increase of bacteria cell count was observed during fermentation. Possible solutions would be to replace ABT culture with pure probiotic cultures, especially Lactobacillus acidophilus and the use of microencapsulation technology or addition of prebiotics would be recommended.

\section{References}

A.O.A.C. (1995): AOAC Official Methods of Analysis, $16^{\text {th }}$ ed., Arlington, USA, Method No. 925.53

Capela, P., Hay, T.K.C. \& Shah, N.P. (2006): Effect of cryoprotectants, prebiotics and microencapsulation on survival of probiotic organisms in yoghurt and freeze-dried yoghurt. Fd Res. Int., 39, 203-211.

DAVE, R.I. \& SHAH, N.P. (1997): Effect of cysteine on the viability of yoghurt and probiotic bacteria in yoghurts made with commercial starter cultures. Int. Dairy J., 7, 537-545. 
Esteve, M.J., Frigola, A., Rodrigo, C. \& Rodrigo, D. (2005): Effect of storage period under variable conditions on the chemical and physical composition and colour of Spanish refrigerated orange juices. Fd Chem. Toxicol., 43, 1413-1422.

FRIC, P. (2007): Probiotics and prebiotics - renaissance of a therapeutic principle. Cent. Eur. J. Med., 2, 237-270.

Garault, P., Letort, C., Juillard, V. \& Monnet, V. (2000): Branched-chain amino acid biosynthesis is essential for optimal growth of Streptococcus thermophilus in milk. Appl. Environ. Microbiol., 66, 5128-5133.

Gruenwald, J. (2009): Novel botanical ingredients for beverages. Clin. Dermatol., 27, 210-216.

Holsinger, V.H., Posati, L.P. \& Devilbiss, E.D. (1974): Whey beverages: a review. J. Dairy Sci., 57, 849-859.

Kailasapathy, K. \& Supriadi, D. (1996): Effect of whey protein concentrate on the survival of Lactobacillus acidophilus in lactose hydrolysed yoghurt during refrigerated storage. Milchwissenschaft, 51, 565-568.

Mitek, M. \& Kalisz, S. (2003): Współczesne poglądy na właściwości przeciwutleniające soków owocowych i warzywnych. (Present trends in antioxidant activity of fruit and vegetable juices.) Przem. Spoż., 5, 37-39.

Okutucu, B., Dinçer, A., Habib, Ö. \& Zihnioglu, F. (2007): Comparison of five methods for determination of total plasma protein concentration. J. Biochem. Biophysic. Meth., 70, 709-711.

Onwulata, C. \& Huth, P. (2008): Whey processing, functionality and health benefits. $1^{\text {st }}$ ed., Blackwell Publishing, USA, pp. 285-385.

Pekkarinen, S.S., Stockmann, H., Schwarz, K., Heinomen, M. \& Hopia, A.I. (1999): Antioxidant activity and partitioning of phenolic acids in bulk and emulsified methyl linoleate. J. Agric. Fd Chem., 47, 3036-3043.

Polish Standard (1998): Produkty spożywcze - Oznaczanie zawartości witaminy C. (Foodstuffs - vitamin C analysis) PKN, Poland. No. PN-A-04019:1998

PN-ISO STANDARD (1998): Analiza sensoryczna-Metodologia-Wytyczne ogólne (Sensory analysis - methodology - general guidelines). PKN, Poland. No. 6658:1998

Rasz, H. (2009): Rynek mleka w latach 2004-2009. (Milk market in 2004-2009). Analizy, Biuro Analiz Sejmowych Vol. 16 (24) Warsaw, pp. 6-14, (http://orka.sejm.gov.pl/WydBAS.nsf/0/045B4120BE7B8FE9C1257681004F 9C78/\$file/Analiza_\%20BAS_2009_24.pdf)

Re, R., Pellegrini, N., Proteggente, A., Pannala, A., Yang, M. \& Rice-Evans, C. (1999): Antioxidant activity applying an improved ABTS radical cation decolorization assay. Free Radic. Biol. Med., 26, 1231-1237.

Rosenthal, I. \& Bernstein, S. (1998): The survival of a commercial culture of bifidobacteria in milk products. Milchwissenschaft, 53, 441-443.

Shimamura, S. \& Ishibashi, N. (1993): Bifidobacteria: research and development in Japan. Fd Technol., 6, $126-134$.

ShiнAтA, A. \& SHAн, N.P. (2002): Influence of addition of proteolytic strains of Lactobacillus delbrueckii subsp. bulgaricus to commercial ABT starter cultures on texture of yoghurt, exopolysaccharide production and survival of bacteria. Int. Dairy J., 12, 765-772.

Singleton, V.L., Orthofer, R. \& Lamulela-Raventos, R.M. (1999): Analysis of total phenols and other oxidation substrates and antioxidants by means of Folin-Ciocalteu reagent. Meth. Enzymol., 299, 152-178.

ZAJĄC, K.B. \& PoDsęDEK, A. (2002): Skład i właściwości przeciwutleniającą wybranych handlowych soków owocowych. (Composition and antioxidant activity of selected fruit beverages available on the market.) Przem. Ferment. Owoc. Warz., 2, 14-16. 